\title{
ANALISIS KESUKSESAN KARIR ALUMNI PROGRAM MAHASISWA BERPRESTASI DI PERGURUAN TINGGI
}

\author{
Zakiyah Salsabila Syafhil \& Lindawati Kartika \\ e-mail: zakiyah.syafhil@gmail.com , lindawati.kartika@gmail.com \\ Departemen Manajemen, Fakultas Ekonomi dan Manajemen, \\ IPB University
}

\author{
Jalan Raya Dramaga Kampus IPB Dramaga Bogor, Jawa Barat 16680
}

\begin{abstract}
Abstrak: Kementerian Pendidikan dan Kebudayaan menyelenggarakan Pemilihan Mahasiswa Berprestasi (PILMAPRES) tingkat nasional sejak 2004. Kompetisi ini mencakup aspek penilaian komprehensif yang meliputi kemampuan akademik, kemampuan berbahasa asing, capaian unggulan, kemampuan menulis ilmiah, dan kepribadian. IPB University merupakan perguruan tinggi yang memiliki reputasi baik dalam ajang tersebut. Penelitian ini dilakukan pada Direktorat Kemahasiswaan dan Pengembangan Karir IPB dengan tujuan untuk mengidentifikasi karakteristik, menganalisis kompetensi alumni berdasarkan kriteria PILMAPRES dan karir pascakampus, serta menganalisis pengaruh kompetensi terhadap kesuksesan karir alumni program PILMAPRES. Pendekatan yang digunakan adalah kuantitatif berupa survei dan studi dokumen dari berbagai hasil kajian yang relevan. Partisipan penelitian merupakan 45 orang alumni Mahasiswa Berprestasi yang mewakili semua fakultas dan sekolah di IPB. Pengumpulan data dilakukan dengan kuesioner yang diberikan melalui internet kepada responden. Data diolah dengan metode analisis deskriptif dan SEM PLS. Mayoritas alumni bekerja sebagai karyawan swasta dengan masa tunggu ratarata empat bulan. Dari analisis SEM-PLS diketahui bahwa variabel capaian unggulan dan kepribadian berpengaruh signifikan terhadap kesuksesan karier, sedangkan kemampuan akademik, kemampuan bahasa asing dan kemampuan penulisan ilmiah tidak berpengaruh signifikan.
\end{abstract}

Kata-kata Kunci: kesuksesan karier, kompetensi, mahasiswa berprestasi, perguruan tinggi, sumber daya manusia

\section{CAREER SUCCESS ANALYSIS OF OUTSTANDING STUDENT PROGRAM ALUMNI AT UNIVERSITY}

\begin{abstract}
The Ministry of Education and Culture has held National Outstanding Students Selection (PILMAPRES) since 2004. This competition covers comprehensive aspects such as academic abilities, foreign language skills, non-academic achievements, scientific writing abilities, and personality. IPB University has a good reputation in this event. This research was conducted at the Directorate of Student Affairs and Career Development of IPB with the objectives to identify the characteristics of outstanding student alumni, analyse alumni competencies based on PILMAPRES criteria and career, and analyse the influence of competence on career success. The approach used is quantitative with primary data from survey and secondary data from various relevant studies. Research participants were 45 outstanding student alumni representing all faculties and schools in IPB. Data collection was carried out by means of a questionnaire given via the internet to respondents. The data were processed using descriptive analysis and SEM-PLS. The majority of alumni work as private employees with a maximum average waiting period of four months. From the SEM-PLS analysis, it is known that the variables of achievements and personality have a significant effect on career success, while academic abilities, foreign language skills, and scientific writing abilities do not have any significant effect.
\end{abstract}

Keywords: career success, competence, higher education, human resource, outstanding students. 


\section{PENDAHULUAN}

Berdasarkan laporan dari UNDP (2019), Indeks Pembangunan Manusia (IPM) Indonesia masih tertinggal jauh jika dibandingkan dengan negara-negara tetangga di Kawasan ASEAN. Ketertinggalan IPM Indonesia berkaitan dengan kualitas pendidikan yang diwakili oleh rendahnya partisipasi pendidikan menengah ke atas. Sesuai dengan data BPS (2019a) bahwa Angka Partisipasi Kasar (APK) Indonesia semakin turun seiring dengan tingkat pendidikan seperti pada Gambar 1.

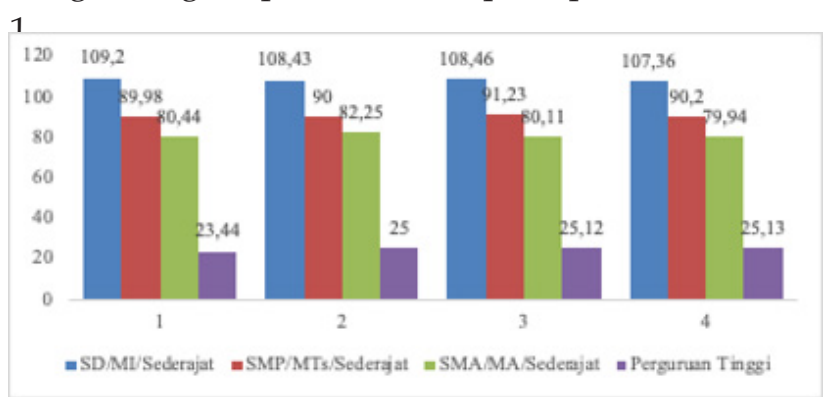

Gambar 1. APK berdasarkan tingkat pendidikan tahun 2016 - 2019 (BPS 2019)

Rendahnya tingkat pendidikan Indonesia berdampak pada rendahnya kualitas angkatan kerja yang masih didominasi oleh tenaga kerja yang tidak berpendidikan tinggi. Hanya ada 13,4 juta orang yang memiliki gelar dari universitas, dan 6,24\% di antaranya termasuk ke dalam pengangguran terbuka (BPS 2019b). Fakta tersebut mengindikasikan adanya skillmismatch antara lulusan dengan kebutuhan industri yang menjadi salah satu alasan utama tingginya angka pengangguran berpendidikan di Indonesia.

Pemerintah pun memaksimalkan peran perguruan tinggi karena dianggap memiliki dampak tercepat dalam menciptakan sumber daya manusia yang unggul (Rogeleonick \& Anugrahmawaty, 2020). Undang-Undang Nomor 12 Tahun 2021 menyatakan bahwa peningkatan kualitas lulusan perguruan tinggi dapat dilakukan dengan mendorong mahasiswa untuk tidak hanya mengikuti pembelajaran di dalam kelas, tetapi juga aktif mengembangkan diri melalui kegiatan kokurikuler dan ekstrakurikuler. Kementerian Riset, Teknologi dan Pendidikan Tinggi (2019), merespon tantangan tersebut dengan mengadakan berbagai kompetisi untuk mengasah keterampilan dan membentuk karakter mahasiswa.

Dari berbagai kompetisi yang dapat diikuti oleh seluruh perguruan tinggi di Indonesia, Pemilihan Mahasiswa Berprestasi (PILMAPRES) merupakan kompetisi paling bergengsi dan unik karena mencakup berbagai aspek kompetensi. Penilaian dalam PILMAPRES mengacu pada lima kompetensi yaitu kemampuan akademik, kemampuan berbahasa asing, capaian unggulan, kemampuan menulis ilmiah, serta kepribadian. Para peserta melewati proses seleksi yang sangat panjang, dimulai dari memilih representasi tingkat departemen atau jurusan, diteruskan ke seleksi di tingkat fakultas, perguruan tinggi, wilayah, hingga tingkat nasional sebagai puncaknya (Kemristekdikti, 2017).

PILMAPRES telah memberikan dampak positif pada budaya berprestasi dan penghargaan terhadap prestasi maupun karya mahasiswa. Selain itu juga dapat mengangkat martabat mahasiswa dan perguruan tingginya melalui model pembinaan mahasiswa secara langsung maupun tidak langsung (Puspresnas, 2020). IPB University merupakan salah satu perguruan tinggi negeri yang rutin mengirimkan mahasiswa terbaiknya untuk mengikuti PILMAPRES Nasional dan memiliki rekam jejak yang baik (DitmawaPK IPB, 2019). IPB University selalu menduduki posisi finalis dan tiga teratas untuk kategori program sarjana. Begitu pula dengan kategori program diploma yang ada sejak tahun 2014. Prestasi IPB University dalam ajang PILMAPRES Nasional diharapkan bisa menjadi gambaran kualitas lulusan yang unggul. Alumni Mahasiswa Berprestasi (Mawapres) dikenal memiliki karier yang cemerlang dan dicari oleh pelaku bisnis maupun profesional. Namun, belum ada penelitian yang secara spesifik menganalisis pengaruh kompetensi alumni Mawapres terhadap kesuksesan karier mereka. Padahal sangat berpotensi untuk dijadikan model menghasilkan lulusan yang berkualitas dan berdaya saing di pasar kerja.

Oleh karena itu, penelitian ini berupaya untuk mengetahui kompetensi dan kesuksesan karier alumni MAWAPRES, serta membuat strategi dalam menciptakan lulusan perguruan tinggi yang berkualitas dengan objek Mawapres IPB University dari setiap fakultas baik program sarjana maupun diploma.

Berdasarkan latar belakang tersebut, maka pertanyaan dalam penelitian ini adalah sebagai berikut: (1) Bagaimana karakteristik alumni Mahasiswa Berprestasi IPB? (2) Bagaimana kompetensi alumni Mahasiswa Berprestasi IPB berdasarkan kriteria PILMAPRES dan karier pascakampus? (3) Bagaimana pengaruh kompetensi alumni Mahasiswa Berprestasi terhadap kesuksesan karier pascakampus?

Sesuai dengan latar belakang dan pertanyaan penelitian, maka tujuan penelitian ini adalah (1) 
Mengidentifikasi karakteristik alumni Mahasiswa Berprestasi IPB (2) Menganalisis kompetensi alumni Mahasiswa Berprestasi IPB berdasarkan kriteria Pilmapres dan karier pascakampus (3) Menganalisis pengaruh kompetensi alumni Mahasiswa Berprestasi terhadap kesuksesan karier pascakampus.

Penelitian ini memberikan kontribusi bagi: (1) Direktorat Kemahasiswaan dan Pengembangan Karier IPB sebagai rekomendasi peningkatan kualitas mahasiswa dan lulusan IPB University (2) Akademisi, sebagai rujukan penelitian selanjutnya terkait Mahasiswa Berprestasi yang masih jarang sekali dilakukan (3) Penulis, sebagai salah satu syarat untuk menyelesaikan studi dan aplikasi ilmu yang diperoleh semasa kuliah khususnya dalam bidang Sumber Daya Manusia serta berkaitan dengan minat penulis di bidang pendidikan.

Terdapat dua teori yang menjadi dasar dalam penelitian ini. Teori pertama berkaitan dengan kompetensi alumni mahasiswa berprestasi. Definisi kompetensi menurut Spencer \& Spencer (1993) merupakan karakteristik yang mendasari seseorang dan berkaitan dengan kinerja unggul dalam pekerjaan atau situasi. Jika mengacu pada Iceberg model atau analogi gunung es Spencer \& Spencer (1993), kompetensi knowledge dan skills cenderung terlihat dan relatif hanya di permukaan. Sedangkan self-concept, traits dan motives lebih tersembunyi, dalam, dekat dengan kepribadian seperti ilustrasi pada Gambar 2.

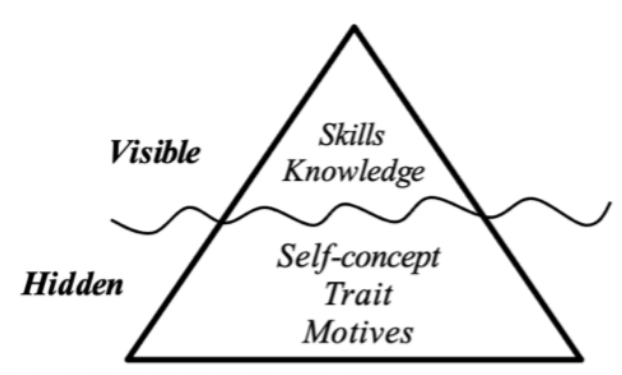

Gambar 2. The Iceberg Model (Spencer \& Spencer 1993)

Dari Iceberg model, terdapat dua pembagian karakteristik dasar seseorang dalam berperilaku atau berpikir, menyamaratakan situasi dan bertahan untuk jangka waktu yang cukup lama, yaitu:

1. Visible Competence (kompetensi tampak) Karakteristik seseorang yang terlihat dapat diperoleh dari pendidikan dan pelatihan yang terdiri dari knowledge (pengetahuan) dan skills (keterampilan).

2. Hidden Competence (Kompetensi yang tidak tampak) Kompetensi yang tidak tampak seperti motif, sifat, dan konsep diri merupakan pusat kepribadian seseorang yang menjadi penyebab munculnya tindakan untuk mencapai suatu hasil (Spencer \& Spencer 1993).

Mahasiswa berprestasi IPB dipilih berdasarkan kompetensi yang merujuk pada Pedoman Pemilihan Mahasiswa Berprestasi Nasional dari Kemenristekdikti (2017) yang terdiri dari:

1. Kemampuan Akademik

Indeks Prestasi Kumulatif (IPK) minimal 3.00 merupakan syarat utama untuk mengikuti Pilmapres yang diharapkan bisa menjadi acuan bahwa seorang mahasiswa mampu mengikuti proses pembelajarannya. Selain itu, untuk desk evaluation di tingkat IPB, seluruh mata kuliah dinyatakan lulus atau huruf mutu terkecil adalah C (DitmawaPK IPB, 2019).

\section{Kemampuan Bahasa Asing}

Bahasa asing merupakan salah satu keterampilan yang penting untuk dimiliki seseorang. Dalam PILMAPRES, ada 6 bahasa asing yang dapat dipilih oleh peserta yaitu Inggris, China, Perancis, Arab, Rusia, dan Spanyol. Penilaian bahasa asing dilakukan melalui dua tahap, yaitu (1) penulisan ringkasan (bukan abstrak) berbahasa asing dari karya tulis ilmiah dan (2) presentasi dan diskusi dalam bahasa Inggris/bahasa asing PBB lainnya. Ringkasan berisi latar belakang, rumusan masalah, metodologi, hasil, dan simpulan.

3. Capaian Unggulan

Capaian unggulan berupa prestasi yang diraih selama menjadi mahasiswa, khususnya kokurikuler dan ekstrakurikuler yang diakui/mendapatkan penghargaan serta berdampak positif bagi perguruan tinggi maupun masyarakat. Setiap peserta maksimal mencantumkan 10 prestasi yang sesuai dengan rambu-rambu berikut:

a. Prestasi melalui Kompetisi Bidang

Bidang-bidang yang dapat dicantumkan meliputi: Keagamaan, Kewirausahaan, Ilmiah/ Penalaran/Akademik, Seni Budaya, Olah Raga, Teknologi \& Sains, serta Inovasi

b. Prestasi Nonkompetisi

Prestasi ditujukan bagi mahasiswa yang dalam berbagai kegiatan seperti:

01. menjalankan bisnis,

02. berperan sebagai adjudicator, juri, wasit, atau coach dalam suatu kegiatan

03. pengabdian masyarakat,

04. memimpin kepanitiaan tingkat provinsi hingga internasional.

c. Karier di Organisasi Kepemudaan/ 


\section{Kemahasiswaan}

Penilaian prestasi ini berdasarkan pada jabatan dan cakupan wilayah organisasi, karena kedua aspek tersebut dapat menggambarkan kemampuan kepemimpinan seseorang. Adapun kategori organisasi yang dimaksud sebagai berikut:

01. Badan Eksekutif Mahasiswa;

02. Senat Mahasiswa;

03. Dewan Perwakilan Mahasiswa;

04. Majelis Permusyawaratan Mahasiswa;

05. Himpunan Mahasiswa;

06. Unit Kegiatan Mahasiswa Badan Semi Otonom;

07. Organisasi profesi mahasiswa;

08. Organisasi sosial kemasyarakatan.

4. Kemampuan Menulis Ilmiah

Karya Tulis Ilmiah (KTI) merupakan salah satu komponen penilaian dalam PILMAPRES untuk meningkatkan gagasan kreatif mahasiswa. Gagasan yang diangkat oleh peserta juga memberikan solusi untuk suatu permasalahan di masyarakat dan belum pernah dipublikasikan sebelumnya.

5. Kepribadian

Hasil dari penilaian kepribadian dipertimbangkan dalam menentukan calon pemenang. Penilaian dilakukan melalui (1) tes tertulis; (2) diskusi kelompok; dan (3) pengamatan terhadap perilaku peserta selama kegiatan berlangsung, misalnya kesantunan dan kedisiplinan. Namun, berkas penilaian tersebut bersifat rahasia, sehingga hanya bisa diketahui oleh mahasiswa bersangkutan dan para dewan juri inti. Sehingga, penelitian ini menggunakan pendekatan teori kepribadian Littauer (1992) untuk mengidentifikasi kepribadian berdasarkan persepsi responden.

Littauer (1992), dalam buku Personality Plus, kepribadian diartikan sebagai perilaku seorang individu secara keseluruhan dengan sistem kecenderungan tertentu yang berinteraksi dengan serangkaian situasi. Littaueur menggolongkan kepribadian manusia menjadi empat tipe yaitu koleris, melankolis, pleghmatis, dan sanguinis. Gambaran sifatsifat setiap kepribadian dalam pekerjaan dijelaskan sebagai berikut:

1. Koleris: Berorientasi pada tujuan, mengorganisir dengan baik, mencari solusi praktis.

2. Melankolis: Perfeksionis, berorientasi pada jadwal, tekun dan teliti.

3. Pleghmatis: Menengahi masalah, baik di bawah tekanan, meng-hindari konflik.
4. Sanguinis: Kreatif dan penuh warna, sukarela dalam bekerja, antusias dan ekspresif.

Teori kedua yaitu kesuksesan karier yang didefinisikan sebagai akumulasi hasil positif terkait pekerjaan dan psikologis yang dihasilkan dari pengalaman kerja seseorang (Oliveira et al., 2016). Secara historis, mayoritas penelitian sebelumnya menilai kesuksesan karier melihat dari faktor objektif seperti jumlah gaji yang diterima setiap bulan dan jabatan (Abele \& Spurk 2009; Lakshmi \&Sumaryono 2019). Komponen penilaian tersebut banyak digunakan karena mudah diakses dan mencerminkan norma sosial. Namun, faktor-faktor objektif tradisional tersebut menjadi kurang selaras dengan pandangan organisasi dan sikap karyawan di era saat ini sehingga diperlukan peran penting dari kesuksesan karier subjektif (Shockley et al., 2015). Ukuran objektif kesuksesan karier mungkin tidak bisa digunakan untuk konteks tempat bekerja yang berbeda-beda berkaitan dengan peraturan yang diterapkan (Oliveira et al., 2016).

Oleh karenaitu, penelitian ini juga menggunakan pendekatan kesuksesan karier subjektif, mengacu pada Career Satisfaction Scale (CSS) yang diperkenalkan oleh Greenhaus et al. (1990). Walaupun terbilang lama, CSS masih banyak digunakan dalam berbagai penelitian terbaru. Skala ini menilai kepuasan mengenai capaian menuju target karier pribadi yang meliputi karier keseluruhan, karier pada usia tertentu, pendapatan, jabatan, dan keterampilan (Spurk, Abele, \& Volmer, 2011).

Selain itu, peneliti menambahkan dua indikator kesuksesan karier sebagai pendukung yaitu capaian target sertifikasi keahlian dan penghargaan atau pengakuan yang diperoleh dari tempat bekerja. Sertifikasi menunjukkan penguasaan individu atas pengetahuan, kompetensi dan kualifikasi tertentu di bidang praktik professional tertentu (Lester et al. 2010; Miracle 2007). Menurut penelitian Weeden (2002), sertifikasi memiliki dampak signifikan terhadap pendapatan rata-rata di berbagai profesi. Sedangkan penghargaan yang diperoleh dari perusahaan penting untuk ditambahkan agar mendapatkan gambaran apakah kinerja seseorang diakui dengan baik oleh tempat bekerja (McDonald \& Hite 2008).

Kedelapan aspek kesuksesan karier dalam penelitian ini adalah:

1. Gaji yang diterima setiap bulan,

2. Kepuasan terhadap karier keseluruhan

3. Capaian karier pada usia saat ini

4. Capaian target pendapatan 
5. Capaian target jabatan

6. Capaian keterampilan dalam pekerjaan

7. Capaian target sertifikasi keahlian

8. Pengakuan atau penghargaan yang diperoleh dari perusahaan

\section{METODE PENELITIAN}

Penelitian ini menggunakan pendekatan kuantitatif dengan profil alumni dan perspektif terhadap kompetensi serta kesuksesan karir diperoleh dari kuesioner daring yang dengan referensi kuesioner tracer study (DKHA IPB 2020). Kuesioner diadaptasi dengan menambah aspek penilaian PILMAPRESNAS dan kesuksesan karier. Sedangkan data dari dokumen berupa penelitian-penelitian terdahulu dan berbagai hasil kajian yang relevan.

Penelitian mendapat dukungan dari Subdirektorat Pengembangan Prestasi dan Reputasi Mahasiswa (Subdit PRPM) IPB untuk menjangkau calon responden melalui grup WhatsApp alumni MAWAPRES yang menjadi finalis di tingkat IPB tahun 2017 dan 2018.

Populasi dalam penelitian ini adalah alumni Mahasiswa Berprestasi IPB tahun 2017 dan 2018 dari program Diploma maupun setiap fakultas untuk program Sarjana. Penentuan sampel menggunakan non-probability sampling dengan jenis purpossive untuk mendapatkan semua kemungkinan kasus yang sesuai dengan kriteria tertentu menggunakan berbagai metode (Neuman, 2014). Menurut teori tracer study, sangat direkomendasikan memilih alumni yang telah lulus satu sampai dua tahun sebagai responden untuk kemudahan akses dan mengetahui kondisi masa transisi pascakuliah, pengalaman kerja, serta awal karier (Schomburg 2016).

Setiap tahunnya, Sekolah Vokasi IPB memilih 4 juara dan 10 fakultas memilih 3 juara untuk program Sarjana dalam ajang Pemilihan Mahasiswa Berprestasi tingkat IPB. Jadi, populasi (N) dalam penelitian ini sebanyak 68 orang. Berdasarkan perhitungan rumus Slovin dengan toleransi kesalahan sampel sebesar $10 \%$. Dari perhitungan rumus Slovin, minimal sampel yang dibutuhkan sebanyak 40 orang. Penelitian ini sudah memenuhi ketentuan minimal dengan total responden sebanyak 45 orang.

Secara keseluruhan, responden sudah mewakili 10 fakultas yaitu Fakultas Pertanian (Faperta), Fakultas Kedokteran Hewan (FKH), Fakultas Perikanan dan Ilmu Kelautan (FPIK), Fakultas Peternakan (Fapet), Fakultas Kehutanan (Fahutan), Fakultas Teknologi
Pertanian (Fateta), Fakultas Matematika dan Ilmu Pengetahuan Alam (FMIPA), Fakultas Ekonomi dan Manajemen (FEM), Fakultas Ekologi Manusia (Fema), dan Sekolah Bisnis untuk program Sarjana dan Sekolah Vokasi atau program Diploma. Setiap tahun, rata-rata semua fakultas mengirimkan 2 perwakilan mahasiswa pada PILMAPRES tingkat IPB. Namun, ada satu perwakilan FPIK dan Fema mengikuti PILMAPRES pada tahun 2017 dan 2018, FEM hanya mengirimkan satu perwakilan pada tahun 2017, dan satu perwakilan dari SB tidak berkenan mengisi kuesioner.

Pengolahan data penelitian ini menggunakan program Microsoft Excel dan SmartPLS dengan analisis deskriptif dan analisis SEM-PLS.

Analisis deskriptif mengidentifikasi pola dalam data untuk menjawab pertanyaan tentang suatu fenomena yang memainkan peran penting dalam proses ilmiah penelitian secara umum maupun bidang pendidikan secara khusus (Dynarski et al., 2017). Data yang akan dianalisis secara deskriptif yaitu karakteristik alumni Mahasiswa Berprestasi mengacu pada kuesioner Tracer Study IPB (DKHA IPB, 2020) mengenai perkuliahan, profesi saat ini, serta tambahan persepsi terhadap kompetensi Mahasiswa Berprestasi (Kemristekdikti, 2017), kesuksesan karier dan kompetensi yang dibutuhkan dalam pekerjaan.

Penelitian menggunakan 4 skala likert dengan jarak sebesar 0,75. Hasil perhitungan skala persepsi dapat dilihat pada Tabel 1.

Tabel 4.

Skala Likert dalam Penelitian

\begin{tabular}{cll}
\hline No & \multicolumn{1}{c}{ Nilai } & \multicolumn{1}{c}{ Skala } \\
\hline 1 & $3,26-4,00$ & Sangat Setuju \\
2 & $1-1,75$ & Sangat Tidak Setuju \\
3 & $1,76-2,50$ & Tidak Setuju \\
4 & $2,51-3,25$ & Setuju \\
\hline
\end{tabular}

Selain analisis deskriptif, penelitian ini juga menggunakan analisis Partial Least Square (PLS) untuk mengolah data dan menjawab hipotesis. Keuntungan PLS meliputi kemampuan untuk memodelkan beberapa variabel dependen serta beberapa variabel independen; kemampuan untuk menangani multikolinearitas di antara variabel independen; ketahanan dalam menghadapi gangguan data yang hilang; dan membuat variabel laten independen secara langsung berdasarkan produk silang yang melibatkan variabel respons, sehingga menghasilkan prediksi yang lebih kuat (Garson, 2016). 
Dalam analisis SEM-PLS terdapat dua tahapan evaluasi yang perlu dilakukan. Tahapan pertama yaitu evaluasi outer model atau model pengukuran bertujuan untuk menilai validitas dan reliabilitas model. Uji validitas dilakukan untuk mengetahui keandalan instrumen penelitian dalam mengukur konstruk. Sementara itu, uji reliabilitas digunakan untuk mengukur konsistensi alat ukur dan konsistensi responden dalam menjawab item pernyataan kuesioner. Dalam ada beberapa syarat yang perlu dipenuhi yaitu:

\section{a. Convergent Validity}

Uji validitas konvergen dinilai berdasarkan nilai loading factor. Ukuran refleksif individual dikatakan tinggi jika berkorelasi lebih dari 0.70 dengan konstruk yang akan diukur dalam penelitian. Dengan demikian, variabel dengan nilai loading factor yang kurang dari 0.70 harus dieliminasi dan dilakukan analisis ulang.

\section{b. Discriminant validity}

Validitas diskriminan diukur dengan membandingkan nilai akar AVE (square root of average variance extracted) setiap konstruk. Jika setiap konstruk lebih besar dari 0,50 maka discriminant validity dalam model dinyatakan baik

\section{c. Composite Reliability}

Uji reliabilitas dilakukan untuk mengukur tingkat konsistensi internal alat ukur dalam PLS. Composite reliability adalah salah satu pengukuran untuk melihat reliabilitas suatu alat ukur. Alat ukur dinyatakan reliabel jika memiliki nilai composite realibility di atas 0.70 dan cronbach's alpha di atas 0,60 .

Selanjutnya tahapan kedua yaitu evaluasi inner model atau model struktural dalam PLS dievaluasi menggunakan R2 (R Square) untuk mengukur tingkat variasi perubahan variabel independen terhadap variabel dependen. Semakin tinggi nilai R2 menandakan bahwa penelitian semakin baik dan terwakilkan oleh model, karena variasi dapat diukur menggunakan alat ukur didalam penelitian. Sedangkan tingkat siginifikansi pengaruh variabel independen terhadap variabel dependen dilakukan dengan melihat nilai path coefficient dan nilai T-satistik PLS diperoleh dari korelasi langsung antara variabel. Nilai T-statistik diperlukan untuk melakukan uji signifikansi dengan selang kepercayaan 95 persen (nilai $\mathrm{T}$ tabel=1.96).

\section{HASIL DAN PEMBAHASAN}

\section{Karakteristik Alumni Mahasiswa Berprestasi}

Responden yang terlibat dalam penelitian ini sebanyak 45 orang perwakilan fakultas dan sekolah dalam ajang PILMAPRES tingkat IPB tahun 2017 dan 2018. Karakteristik dibedakan secara umum pada Gambar 3, semasa kuliah di IPB pada Gambar 4 dan karakteristik pada tahun 2020 pada Gambar 5.

Dari 45 orang responden, terdapat 9 orang alumni dari program Diploma dan 36 orang alumni dari program Sarjana. Karakteristik alumni Mawapres IPB dari kedua program didominasi oleh laki-laki yaitu sebanyak $78 \%$ alumni Diploma dan $58 \%$ alumni Sarjana. Domisili responden saat pengambilan data cukup beragam. Jika dikelompokkan, domisili paraalumni Mawapres IPB didominasi pada area Jakarta, Bogor, Tangerang, dan Bekasi (Jabotabek) sebanyak $60 \%$, disusul luar Jabotabek sebanyak 33\%, dan 7\% berada di luar negeri. Semua responden yang berada di luar negeri sedang menjalani masa studi S2 di Turki, Finlandia, dan Polandia.

Selanjutnya, karakteristik semasa kuliah dilihat dari Indeks Prestasi Kumulatif (IPK) menunjukkan angka yang relatif tinggi. Jika dibagi ke dalam 3 kelas, mayoritas berada pada interval nilai IPK 3,73 - 4,00 sebanyak $44 \%$, disusul interval 3,46 - 3,72 sebanyak $33 \%$, dan $3,20-3,45$ sebanyak $22 \%$ dari total responden.

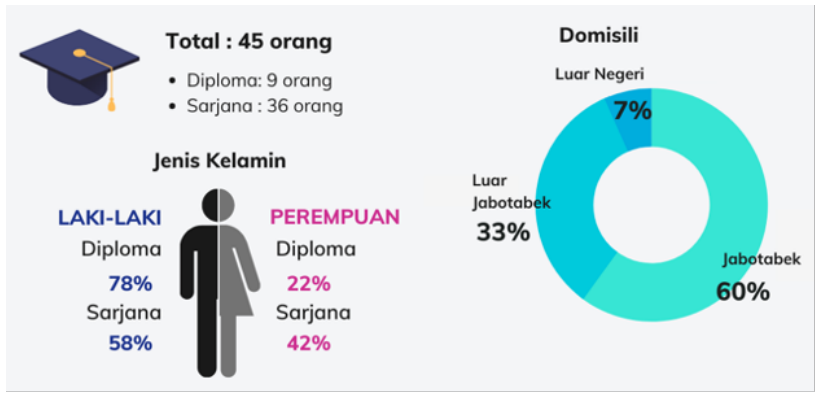

Gambar 3. Karakteristik Umum Responden

Selain IPK, karakteristik semasa kuliah dilihat dari masa studi untuk kedua program. Mayoritas alumni Mawapres IPB menyelesaikan studi tepat waktu yaitu 36 bulan, sedangkan mayoritas sebanyak $65 \%$ alumni Sarjana lulus dalam kurun waktu 42 sampai 48 bulan. Angka tersebut membuktikan komitmen para alumni MAWAPRES IPB untuk menyeimbangkan kualitas antara akademik dan nonakademik. Bagi yang melewati masa studi tersebut, terdapat tiga alasan utama yaitu mengikuti aktifitas kemahasiswaan, kendala pengerjaan tugas akhir, dan sudah mulai bekerja seperti yang tersaji pada Gambar 4. 


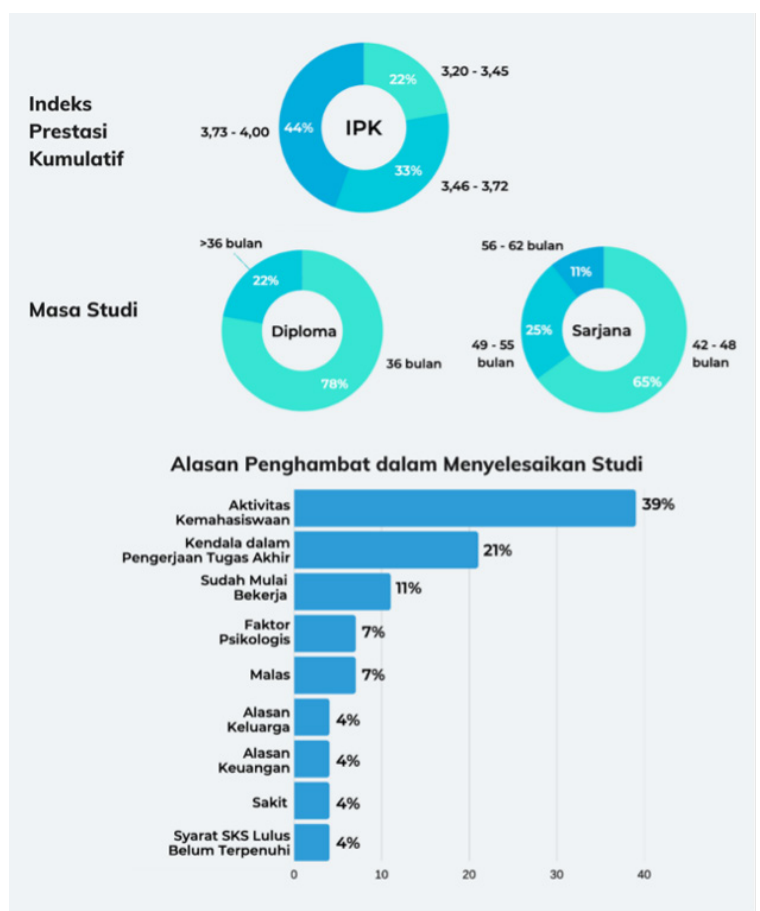

Gambar 4. Karakteristik Responden Semasa Kuliah

Setelah menyelesaikan studi, total ada 33 alumni MAWAPRES IPB yang sedang bekerja. Mayoritas berprofesi sebagai karyawan swasta sebanyak 49\%, wirausaha sebanyak 13\%, mahasiswa Program Pendidikan Dokter Hewan (PPDH) sebanyak 11\%, mahasiswa S2 sebanyak 9\%, karyawan di organisasi nirlaba sebanyak 7\%, Pegawai Negeri Sipil (PNS) sebanyak $4 \%$, dan yang belum bekerja ada $7 \%$. Data yang menarik perhatian peneliti yaitu jumlah rendahnya alumni yang menjadi wirausaha karena salah satu visi baru dari IPB yaitu mencetak technosociopreneurs atau wirausaha yang berbasis teknologi dan sosial (IPB University, 2020).

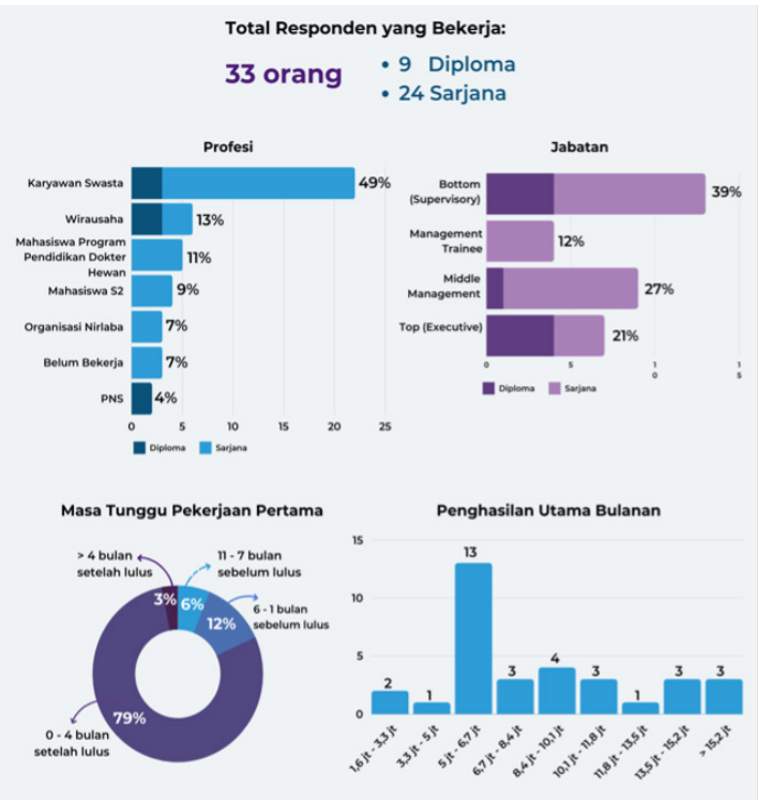

Gambar 5 Karakteristik Responden Tahun 2020
Jabatan pekerjaan alumni MAWAPRES IPB terbagi menjadi tiga tingkatan mengacu pada Kaiser et al. (2011) mulai dari yang terendah yaitu bottom (supervisory), middle management, hingga top (executive). Peneliti menambahkan Management Trainee (MT) sebagai satu jabatan di antara level bottom dan middle management. Karena mereka yang diterima sebagai MT dalam suatu perusahaan telah melewati serangkaian seleksi khusus untuk dipersiaplan menduduki posisi manajerial (Ikhsan, 2019).

Dari data responden yang terkumpul, mayoritas sebanyak 39\% alumni MAWAPRES IPB memiliki jabatan pada level bottom (supervisory), diikuti $27 \%$ pada level middle management, $21 \%$ pada level top (executive), dan 9\% pada level Management Trainee. Berbagai aspek unggul yang dimiliki alumni MAWAPRES IPB seperti kecerdasan, pengalaman organisasi yang memadai serta penguasaan Bahasa Inggris sangat dicari diutamakan perusahaan dalam mencari kandidat terbaik untuk menduduki level jabatan menengah ke atas (Ikhsan, 2019).

Jika dilihat dari masa tunggu pekerjaan pertama, waktunya relatif singkat. Mayoritas sebanyak 79\% alumni MAWAPRES IPB mendapatkan pekerjaan pertama mereka dalam kurun waktu 0 - 4 bulan setelah lulus dan hanya 3\% di atas 4 bulan setelah lulus. Selain itu, ada $12 \%$ alumni yang mendapatkan pekerjaan pertama $1-6$ bulan sebelum lulus dan 6\% dalam 11 - 7 bulan sebelum lulus. Dari data tersebut, dapat disimpulkan bahwa alumni MAWAPRES IPB sangat cepat diserap oleh pasar kerja.

Penghasilan utama responden dibagi ke dalam sembilan kelas. Mayoritas 39\% alumni Mawapres IPB memiliki pendapatan utama pada rentang $\mathrm{Rp}$ 5.000.000 sampai $\operatorname{Rp~6.700.000,~disusul~12\% ~pada~}$ rentang Rp8.400.000 sampai Rp10.100.000 dan sisanya beragam dapat dilihat pada Gambar 5 .

\section{Kompetensi Alumni Mahasiswa Berprestasi IPB Berdasarkan Kriteria PILMAPRES dan Kesuksesan Karier Pascakampus}

Analisis deskriptif selanjutnya memperlihatkan persepsi responden terhadap kompetensi berdasarkan kriteria dan karier pascakampus alumni MAWAPRES IPB. Dalam kuesioner, responden diminta untuk 
memilih satu jawaban untuk setiap pernyataan dengan skala likert 1-4. Data disajikan menggunakan pendekatan mean agar dapat melihat rata-rata setiap aspek dengan lebih mudah. Penyajian data terbagi menjadi dua yaitu Kompetensi Alumni MAWAPRES IPB dan Kesuksesan Karier Pascakampus.

Kompetensi yang dimaksud sesuai dengan kriteria penilaian dalam Pedoman Pemilihan Mahasiswa Berprestasi dari Kemenristekdikti (2017) yang terdiri dari kemampuan akademik, kemampuan bahasa asing, capaian unggulan, kemampuan menulis ilmiah, dan kepribadian. Setiap aspek Mawapres didapat dari persepsi responden menggunakan skala likert 1 sampai 4 dengan pendekatan mean. Khusus untuk aspek penilaian Kepribadian mengadaptasi konsep Personality Plus Littauer (1992). Tabel 2 menunjukkan hasil persepsi MAWAPRES IPB terhadap dua kriteria pertama yaitu kemampuan akademik dan kemampuan Bahasa asing.

Tabel 2.

Persepsi Alumni MAWAPRES IPB Terhadap Kemampuan Akademik dan Kemampuan Bahasa Inggris

\begin{tabular}{|c|c|c|c|c|}
\hline \multirow{2}{*}{$\begin{array}{c}\text { Aspek } \\
\text { Penilaian }\end{array}$} & \multicolumn{2}{|c|}{ Diploma } & \multicolumn{2}{|c|}{ Sarjana } \\
\hline & Nilai & Keterangan & Nilai & Keterangan \\
\hline \multicolumn{5}{|c|}{ 1. Kemampuan Akademik } \\
\hline $\begin{array}{l}\text { Indeks } \\
\text { Prestasi } \\
\text { Kumulatif }\end{array}$ & 3,74 & $\begin{array}{l}\text { De n g a n } \\
\text { Pujian }\end{array}$ & 3,61 & $\begin{array}{l}\text { Dengan } \\
\text { Pujian }\end{array}$ \\
\hline $\begin{array}{l}\text { Nilai } \\
\text { akademis } \\
\text { tingkat } \\
\text { satu di } \\
\text { atas rata- } \\
\text { rata }\end{array}$ & 3,33 & $\begin{array}{l}\text { S a n g a } t \\
\text { Setuju }\end{array}$ & 3,53 & $\begin{array}{l}\text { S a n g a t } \\
\text { Setuju }\end{array}$ \\
\hline
\end{tabular}

\begin{tabular}{|c|c|c|c|c|}
\hline $\begin{array}{l}\text { Huruf } \\
\text { mutu } \\
\text { pada mata } \\
\text { kuliah } \\
\text { mayor } \geq \text { B }\end{array}$ & 3,56 & $\begin{array}{l}\text { S a n g a t } \\
\text { Setuju }\end{array}$ & 3,06 & Setuju \\
\hline
\end{tabular}

\begin{tabular}{|c|c|c|c|c|}
\hline $\begin{array}{l}\text { Huruf } \\
\text { mutu } \\
\text { pada mata } \\
\text { kuliah } \\
\text { supporting } \\
\text { course / } \\
\text { minor } \geq \text { B }\end{array}$ & 3,33 & $\begin{array}{l}\text { S a n g a t } \\
\text { Setuju }\end{array}$ & 3,25 & Setuju \\
\hline $\begin{array}{l}\text { Huruf } \\
\text { mutu } \\
\text { tugas } \\
\text { akhir / } \\
\text { skripsi } \geq \text { B }\end{array}$ & 3,89 & $\begin{array}{l}\text { S a n g a t } \\
\text { Setuju }\end{array}$ & 3,81 & $\begin{array}{l}\text { S a ng a t } \\
\text { Setuju }\end{array}$ \\
\hline
\end{tabular}

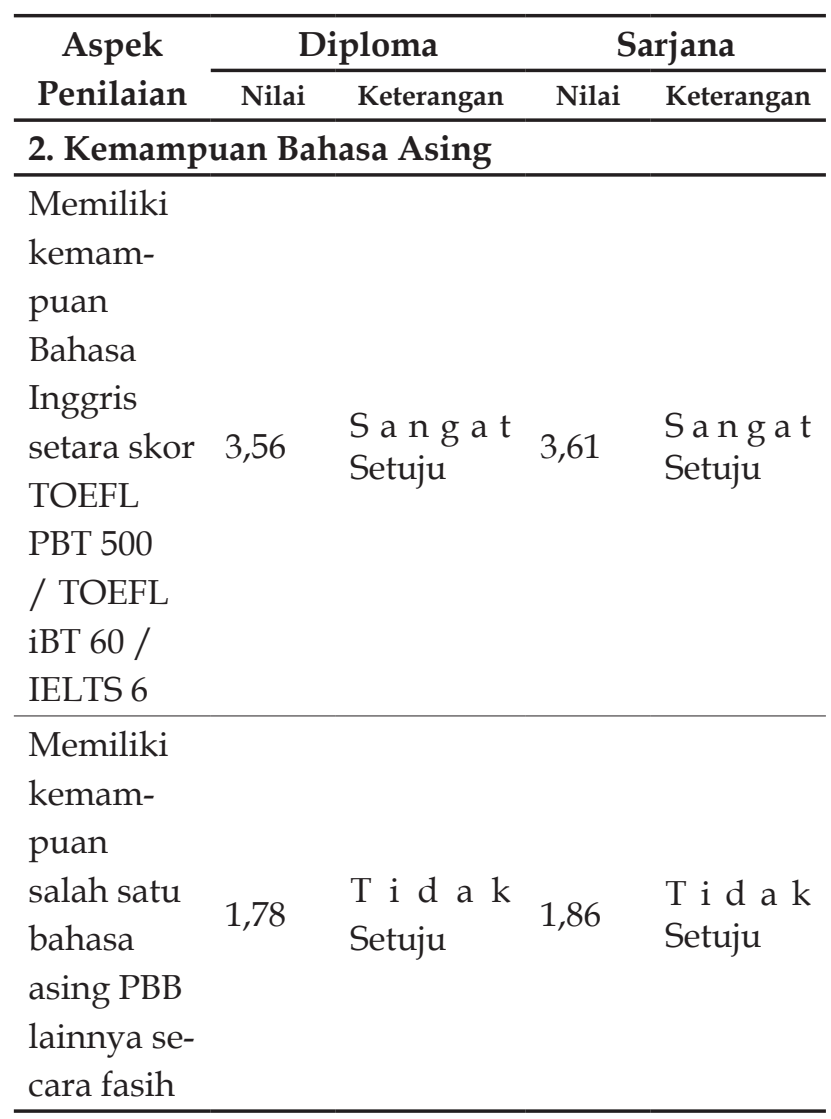

Dari Tabel 2, diketahui bahwa alumni Mawapres IPB memiliki kemampuan akademik yang baik dengan IPK rata-rata 3,74 untuk Diploma dan 3,61 untuk Sarjana serta didukung rata-rata tertinggi pada huruf mutu tugas akhir setara B atau lebih. Nilai tersebut sudah melampaui syarat minimal untuk mengikuti Pilmapres yaitu 3,00 (Kemristekdikti, 2017).

Kemampuan Bahasa asing dalam penelitian ini terdiri dari kemampuan Bahasa Inggris dan kemampuan Bahasa asing PBB lainnya yaitu Bahasa Arab, Mandarin, Prancis, Rusia dan Spanyol. Rata-rata alumni Mawapres dari kedua program sudah memiliki kemampuan Bahasa Inggris yang baik yaitu setara skor TOEFL 500 atau lebih. Skor tersebut sudah memenuhi persyaratan untuk mendaftar program beasiswa Magister atau sudah di atas rata-rata kemampuan Bahasa Inggris mahasiswa program Diploma maupun Sarjana (LPDP, 2020). Namun, rata-rata alumni tidak memiliki kemampuan Bahasa asing PBB lainnya secara fasih. Kemungkinan, semasa kuliah kemampuan tersebut dianggap kurang penting oleh alumni Mawapres sehingga tidak begitu dipelajari atau dilatih. Aspek penilaian selanjutnya yaitu capaian unggulan yang tersedia pada Tabel 3. 
Tabel 3.

Persepsi Alumni MAWAPRES IPB Terhadap Capaian Unggulan

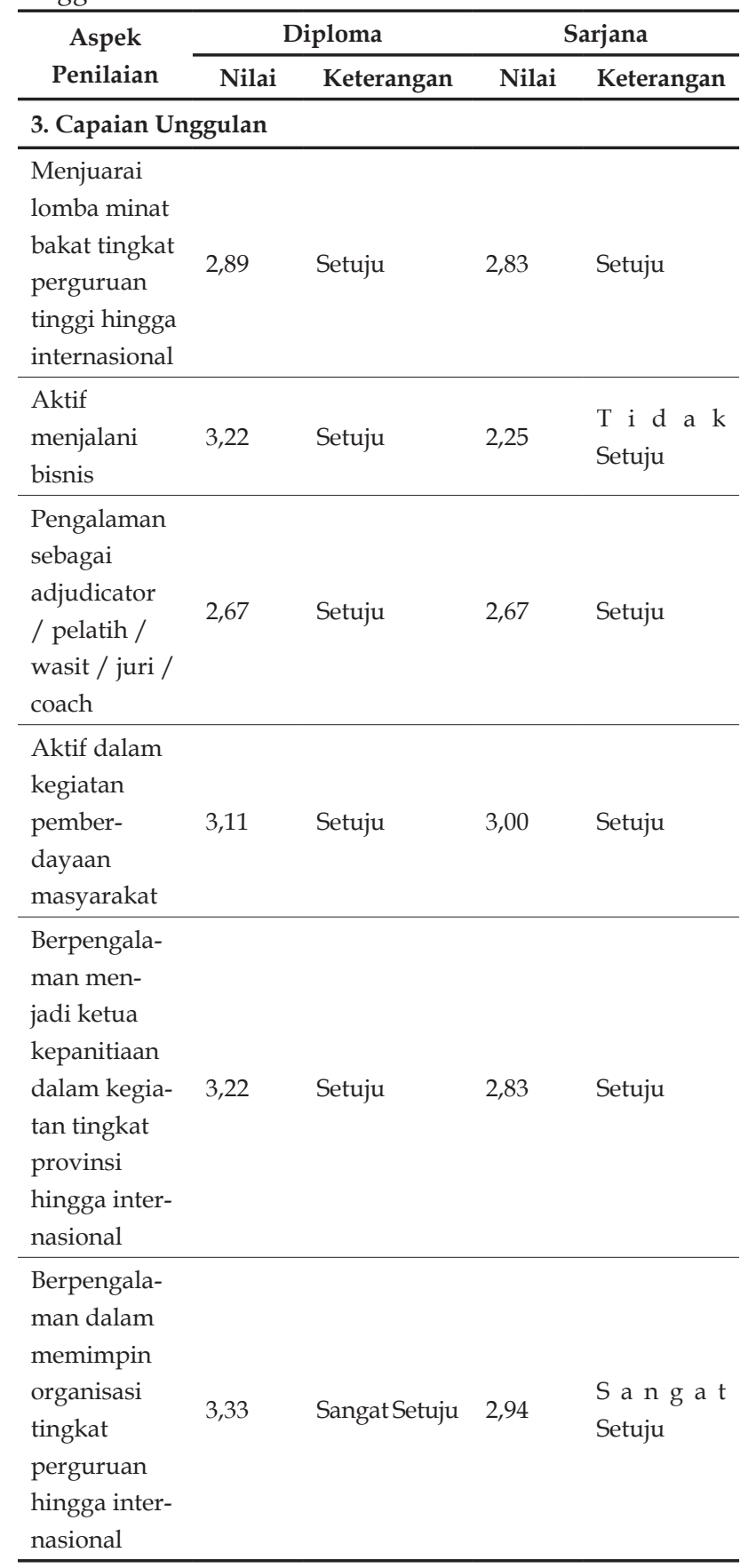

Jenis capaian unggulan dalam Pilmapres sangat beragam. Untuk program Diploma, rata-rata tertinggi terdapat pada pengalaman dalam memimpin organisasi mulai dari tingkat perguruan tinggi hingga internasional dengan nilai 3,33. Keaktifan alumni Mawapres dalam memimpin organisasi dapat meningkatkan motivasi belajar, kemampuan berkomunikasi dan mengasak kepemimpinan yang sangat berguna dalam pekerjaan (Yusuf \& Mabagits, 2020). Sedangkan rata-rata tertinggi untuk program Sarjana terdapat pada keaktifan dalam kegiatan pemberdayaan masyarakat dengan nilai 3,00. Menurut Gregorová (2016), kegiatan tersebut dapat digunakan untuk mengembangkan pengetahuan, keterampilan, sikap, dan perilaku yang diperlukan untuk bekerja dalam lingkungan berbasis tim kolaboratif. Selanjutnya beralih kepada aspek penilaian keempat yaitu kemampuan menulis ilmiah.

Aspek kemampuan dalam menulis Karya Tulis Ilmiah idealnya dinilai berdasarkan naskah yang dikumpulkan dan presentasi saat mengikuti Pilmapres. Namun, karena keterbatasan data, penelitian ini menggunakan pendekatan lain seperti pengalaman dalam menghasilkan karya tulis ilmiah selain tugas akhir dan pengalaman dalam menjuarai lomba bidang teknologi, sains dan inovasi dengan hasil tersedia pada Tabel 4.

Tabel 4.

Persepsi Alumni MAWAPRES IPB Terhadap Kemampuan Menulis Ilmiah

\begin{tabular}{|c|c|c|c|c|}
\hline \multirow{2}{*}{$\begin{array}{c}\text { Aspek } \\
\text { Penilaian }\end{array}$} & \multicolumn{2}{|c|}{ Diploma } & \multicolumn{2}{|c|}{ Sarjana } \\
\hline & Nilai & Keterangan & Nilai & Keterangan \\
\hline \multicolumn{5}{|c|}{ 4. Kemampuan Menulis Ilmiah } \\
\hline $\begin{array}{l}\text { Selama } \\
\text { kuliah } \\
\text { pernah } \\
\text { meng- } \\
\text { hasilkan } \\
\text { lebih dari } \\
\text { atau sama } \\
\text { dengan } \\
\text { satu KTI } \\
\text { (selain tu- } \\
\text { gas akhir) }\end{array}$ & 3,22 & Setuju & 3,19 & Setuju \\
\hline $\begin{array}{l}\text { Pernah } \\
\text { menjua- } \\
\text { rai lom- } \\
\text { ba-lomba } \\
\text { bidang } \\
\text { teknologi, } \\
\text { sains, dan } \\
\text { inovasi } \\
\text { tingkat } \\
\text { pergutu- } \\
\text { an tinggi } \\
\text { hingga } \\
\text { internasi- } \\
\text { onal }\end{array}$ & 3,11 & Setuju & 2,56 & Setuju \\
\hline
\end{tabular}

Hasil yang diperoleh untuk indikator pertama menunjukkan bahwa rata-rata alumni Mawapres IPB pernah menghasilkan lebih dari satu karya tulis ilmiah selain tugas akhir dengan nilai 3,22 untuk program Diploma dan 3,19 untuk program Sarjana. Kemudian dari indikator kedua dapat diketahui bahwa 
alumni MAWAPRES IPB pernah menjuarai lomba berbagai bidang yang berkaitan dengan kepenulisan ilmiah. Sehingga, dapat disimpulkan bahwa alumni MAWAPRES IPB memiliki kemampuan menulis ilmiah yang baik. Menulis ilmiah bukan kegiatan yang mudah. Diperlukan berbagai kemampuan seperti pemahaman kosakata yang luas, membaca dan memahami literatur, hingga kemampuan pengelolaan waktu yang baik (Sunggingwati, 2018).

Aspek penilaian terakhir dalam PILMAPRES yaitu kepribadian. Untuk mendapatkan gambaran yang paling mendekati mengenai kepribadian MAWAPRES, biasanya dilakukan tiga asesmen oleh psikolog seperti tes tertulis, focus group discussion dan wawancara personal. Namun, hasilnya bersifat rahasia sehingga hanya bisa diakses oleh psikolog, mahasiswa terkait, dan dewan juri inti pada PILMAPRES. Penelitian ini mengunakan pendekatan Personality Plus (Littauer, 1992) yang terdiri dari Koleris, Melankolis, Pleghmatis, dan Sanguinis untuk melihat persepsi alumni MAWAPRES IPB terhadap kecenderungan tipe kepribadiannya seperti yang disajikan pada tabel 5 .

Tabel 5.

Persepsi Alumni MAWAPRES IPB Terhadap Empat Tipe Kepribadian

\begin{tabular}{|c|c|c|c|c|}
\hline \multirow{2}{*}{$\begin{array}{c}\text { Aspek } \\
\text { Penilaian }\end{array}$} & \multicolumn{2}{|c|}{ Diploma } & \multicolumn{2}{|c|}{ Sarjana } \\
\hline & Nilai & Keterangan & Nilai & Keterangan \\
\hline \multicolumn{5}{|c|}{ 5. Kepribadian } \\
\hline $\begin{array}{l}\text { Kecend- } \\
\text { erungan } \\
\text { terhadap } \\
\text { kepribadi- } \\
\text { an Koleris }\end{array}$ & 3,33 & $\begin{array}{l}\text { S a n g a t } \\
\text { Setuju }\end{array}$ & 3,14 & Setuju \\
\hline $\begin{array}{l}\text { Kecend- } \\
\text { erungan } \\
\text { terhadap } \\
\text { kepribadi- } \\
\text { an Melan- } \\
\text { kolis }\end{array}$ & 2,67 & Setuju & 3,03 & Setuju \\
\hline $\begin{array}{l}\text { Kecend- } \\
\text { erungan } \\
\text { terhadap } \\
\text { kepribadi- } \\
\text { an Plegh- } \\
\text { matis }\end{array}$ & 2,89 & Setuju & 2,83 & Setuju \\
\hline $\begin{array}{l}\text { Kecend- } \\
\text { erungan } \\
\text { terhadap } \\
\text { kepribadi- } \\
\text { an Sangui- } \\
\text { nis }\end{array}$ & 2,78 & Setuju & 2,97 & Setuju \\
\hline
\end{tabular}

Dari penilaian persepsi diperoleh hasil yang menarik. Rata-rata tertinggi alumni MAWAPRES IPB sama yaitu pada kecenderungan terhadap kepribadian Koleris dengan nilai 3,33 untuk program Diploma dan 3,14 untuk program Sarjana. Beberapa sifat dari kepribadian tipe Koleris yaitu mampu mengorganisir dengan baik dan memiliki orientasi pada tujuan (Littauer, 1992). Sedangkan kecenderungan terhadap tiga kepribadian lainnya memiliki nilai rata-rata yang tidak begitu tinggi.

Untuk mengetahui kesuksesan karier pascakampus alumni MAWAPRES IPB, peneliti menilai dari persepsi responden. Total terdapat 33 alumni MAWAPRES IPB yang sedang bekerja dengan proporsi 9 orang dari program Diploma dan 24 orang dari program Sarjana. Hasilnya diolah menggunakan pendekatan mean yang dapat dilihat pada Tabel 6 .

Tabel 6 .

Persepsi Responden terhadap Kesuksesan Karier Pascakampus

\begin{tabular}{lllll}
\hline \multirow{2}{*}{$\begin{array}{c}\text { Aspek } \\
\text { Penilaian }\end{array}$} & \multicolumn{2}{c}{ Diploma } & \multicolumn{2}{c}{ Sarjana } \\
\cline { 2 - 4 } & Nilai & Ket. & Nilai & Ket. \\
\hline 5. Kepribadian & & & \\
\hline Pendapatan & Rp11.888. & Rp9.123. & \\
Bulanan & 889 & 542 & \\
\hline
\end{tabular}

\section{Hubungan}

antara

bidang $\quad 3,11 \quad$ Erat 2,96 Erat

studi dan

pekerjaan

\begin{tabular}{|c|c|c|c|c|}
\hline $\begin{array}{l}\text { Tingkat } \\
\text { pendidikan } \\
\text { untuk } \\
\text { pekerjaan } \\
\text { saat ini }\end{array}$ & 3,22 & $\begin{array}{l}\text { Ting- } \\
k \text { a } t \\
\text { yang } \\
\text { sama }\end{array}$ & 3,17 & $\begin{array}{l}\text { Tingkat } \\
\text { y a } \mathrm{n} g \\
\text { sama }\end{array}$ \\
\hline $\begin{array}{l}\text { Kesuksesan } \\
\text { karier se- } \\
\text { cara umum }\end{array}$ & 2,44 & $\begin{array}{l}\text { Tidak } \\
\text { Setu- } \\
\text { ju }\end{array}$ & 2,42 & $\begin{array}{l}\text { Ti d a k } \\
\text { Setuju }\end{array}$ \\
\hline $\begin{array}{l}\text { Kesuksesan } \\
\text { karier ra- } \\
\text { ta-rata pada } \\
\text { usia saat ini }\end{array}$ & 2,67 & $\begin{array}{l}\text { Setu- } \\
\text { ju }\end{array}$ & 2,71 & Setuju \\
\hline $\begin{array}{l}\text { Target } \\
\text { Pendapatan }\end{array}$ & 2,44 & $\begin{array}{l}\text { Tidak } \\
\text { Setu- } \\
\text { ju }\end{array}$ & 2,88 & Setuju \\
\hline $\begin{array}{l}\text { Target } \\
\text { Jabatan }\end{array}$ & 2,56 & $\begin{array}{l}\text { Setu- } \\
\text { ju }\end{array}$ & 2,63 & Setuju \\
\hline $\begin{array}{l}\text { Target ket- } \\
\text { erampilan } \\
\text { yang ingin } \\
\text { dimiliki }\end{array}$ & 2,67 & $\begin{array}{l}\text { Setu- } \\
\text { ju }\end{array}$ & 2,50 & $\begin{array}{l}\text { T i d a k } \\
\text { Setuju }\end{array}$ \\
\hline $\begin{array}{l}\text { Target } \\
\text { sertifikasi } \\
\text { keahlian }\end{array}$ & 2,67 & $\begin{array}{l}\text { Setu- } \\
\text { ju }\end{array}$ & 2,29 & $\begin{array}{l}\text { Tid a k } \\
\text { Setuju }\end{array}$ \\
\hline
\end{tabular}




\begin{tabular}{lllll}
\hline \multirow{2}{*}{$\begin{array}{c}\text { Aspek } \\
\text { Penilaian }\end{array}$} & \multicolumn{2}{c}{ Diploma } & \multicolumn{2}{c}{ Sarjana } \\
\cline { 2 - 5 } & Nilai & Ket. & Nilai & Ket. \\
\hline $\begin{array}{l}\text { Target } \\
\text { reward dari }\end{array}$ & 3,00 & $\begin{array}{l}\text { Setu- } \\
\text { ju }\end{array}$ & 2,42 & $\begin{array}{l}\text { Tida k } \\
\text { perusahaan }\end{array}$ \\
\hline
\end{tabular}

Dari segi karier pascakampus, diketahui bahwa rata-rata pendapatan per bulan alumni MAWAPRES IPB relatif jauh lebih tinggi dari rata-rata pendapatan per bulan fresh graduates pada umumnya dengan pengalaman kerja dalam rentang satu sampai tiga tahun. Untuk alumni MAWAPRES Diploma sebesar Rp11.888.889 lebih tinggi daripada alumni MAWAPRES Sarjana yaitu sebesar Rp9.123.542. Perbedaan tersebut kemungkinan besar dipengaruhi oleh jumlah sampel alumni MAWAPRES Diploma yang jauh lebih sedikit diperkuat dengan angka pendapatan per bulan yang sangat tinggi karena sudah menduduki jabatan strategis pada usaha yang dikelola.

Selanjutnya dari segi relevansi kompetensi dengan pekerjaan, dapat diketahui bahwa rata-rata alumni kedua program memiliki pekerjaan yang berhubungan erat dengan program studi yang diambil di IPB dengan nilai 3,11 untuk program Diploma dan 2,96 untuk program Sarjana. Selain itu diketahui pula bahwa rata-rata alumni program Diploma dan Sarjana berada pada tingkat pendidikan yang sama untuk pekerjaan saat ini dengan nilai masing-masing sebesar 3,22 dan 3,17.

Kesamaan pada kedua program terdapat pada nilai rata-rata alumni kedua program Setuju bahwa mereka sudah mencapai kesuksesan rata-rata untuk usia saat ini dan sudah mencapai target jabatan di usia yang relatif muda.

Jika diperhatikan lebih lanjut, nilai rata-rata tertinggi alumni program Diploma yaitu pada target reward / recognition dari perusahaan dengan nilai 3,00. Angka tersebut menggambarkan bahwa alumni MAWAPRES Diploma cukup diakui oleh perusahaan dari segi kinerja dan kontribusinya dalam pekerjaan. Sedangkan nilai rata-rata terendah yaitu pada kepuasan terhadap target penghasilan dengan nilai 2,44. Padahal, secara nominal rata-ratanya berada lebih tinggi daripada alumni MAWAPRES Sarjana.

Kemudian dari program Sarjana, dapat diketahui bahwa indikator target pendapatan memiliki nilai rata-rata tertinggi dengan nilai 2,88 dan target sersertifikasi keahlian memiliki nilai rata-rata terendah sebesar 2,29. Angka tersebut memiliki arti bahwa ratarata alumni MAWAPRES IPB program Sarjana sudah mencapai target pendapatan tetapi belum mencapai target sertifikasi keterampilan.
Keduanya sesuai dengan tahap early career menurut Greenhaus et al. (2010) yaitu ketika seseorang perlu meningkatkan kompetensinya untuk mencapai tujuan karier.

\section{Pengaruh Kompetensi Alumni Mahasiswa Berprestasi IPB terhadap Kesuksesan Karier Pascakampus}

Pengaruh karakteristik alumni Mahasiswa Berprestasi dengan kesuksesan karier pascakampus dianalisis menggunakan SEM pendekatan Partial Least Square (PLS) melalui aplikasi SmartPLS 3.3.2. Analisis ini bertujuan untuk melihat bentuk dan pengaruh langsung variabel laten eksogen yaitu Kemampuan Akademik (X1), kemampuan Bahasa Inggris dan Bahasa PBB lainnya (X2), capaian unggulan (X3), kemampuan membuat Karya Tulis Ilmiah (X4), dan Kepribadian (X5) terhadap laten endogen yaitu Kesuksesan Karier (Y). Analisis ini terdiri dari dua tahap yaitu evaluasi model pengukuran (outer model) dan evaluasi model struktural (inner model). Penting untuk menetapkan reliabilitas dan validitas variabel laten dalam melengkapi pemeriksaan model struktural.

Pada Tabel 7 disajikan hasil evaluasi outer model dan inner model secara rinci berdasarkan kriteria model penilaian PLS.

Tabel 7.

Hasil Evaluasi Outer Model dan Inner Model Pada Model Penelitian

\begin{tabular}{|c|c|c|c|}
\hline No & $\begin{array}{l}\text { Kriteria } \\
\text { Evaluasi }\end{array}$ & Syarat & $\begin{array}{c}\text { Model } \\
\text { Penelitian }\end{array}$ \\
\hline \multicolumn{4}{|c|}{ Evaluasi Model Pengukuran (Outer Model) } \\
\hline 1 & $\begin{array}{l}\text { Lo a ding } \\
\text { factor }\end{array}$ & Lebih dari 0.700 & $\begin{array}{l}\text { R e d u k i } \\
14 \text { variabel } \\
m a n i f e s t \\
\text { dengan nilai } \\
\text { kurang dari } \\
0.70 \\
\text { (Valid) }\end{array}$ \\
\hline 2 & $\begin{array}{l}\text { Average } \\
\text { Variance } \\
\text { Extracted } \\
(\mathrm{AVE})\end{array}$ & Lebih dari 0.500 & $\begin{array}{l}\text { CU: } 0,818 \\
\text { KT: } 1,000 \\
\text { KA: } 0,644 \\
\text { KB:1,000 } \\
\text { KP: } 1,000 \\
\text { SK: } 0,601 \\
\text { (Valid) }\end{array}$ \\
\hline 3 & Cross loading & $\begin{array}{l}\text { Lebih besar } \\
\text { dari indikator } \\
\text { pada variabel } \\
\text { laten lainnya }\end{array}$ & $\begin{array}{l}\text { Semua loading } \\
\text { blok indikator } \\
>\text { indikator } \\
\text { variabel laten } \\
\text { lain } \\
\text { (Valid) }\end{array}$ \\
\hline
\end{tabular}




\begin{tabular}{cccl}
\hline No & $\begin{array}{c}\text { Kriteria } \\
\text { Evaluasi }\end{array}$ & Syarat & $\begin{array}{c}\text { Model } \\
\text { Penelitian }\end{array}$ \\
\hline & & CU: 0,900 \\
& & KT: 1,000 \\
& & KA: 0,844 \\
4 & Composite & Lebih dari 0.600 & KB: 1,000 \\
& KP: 1,000 \\
& & SK: 0,789 \\
& & & (Reliability \\
& & & \\
\hline
\end{tabular}

\begin{tabular}{|c|c|c|c|}
\hline \multicolumn{4}{|c|}{ Evaluasi model struktural (inner model) } \\
\hline 1 & $\begin{array}{l}\text { Estimasi } \\
\text { koefisien } \\
\text { jalur }\end{array}$ & $\begin{array}{l}\text { Nilai estimasi } \\
\text { h u b u n g } n \\
\text { jalur dalam } \\
\text { model harus } \\
\text { signifikan. Nilai } \\
\text { signifikansi } \\
\text { d i p e r o l e h } \\
\text { d e n g a n } \\
\text { p r o s e d u r } \\
\text { bootstrapping. } \\
\text { Nilai t-statistik } \\
\text { lebih dari } 1.96 \\
(5 \%)\end{array}$ & $\begin{array}{l}\mathrm{KP} \rightarrow \mathrm{SK}: \\
\mathbf{3 . 1 2 8} \\
\mathrm{CU} \rightarrow \mathrm{SK}: \\
\mathbf{2 , 1 2 8} \\
\mathrm{KA} \rightarrow \mathrm{SK}: \\
1,773 \\
\mathrm{KT} \rightarrow \mathrm{SK}: \\
1,322 \\
\mathrm{~KB} \rightarrow \mathrm{SK}: \\
1,079 \\
\text { ( b e r p e n - } \\
\text { garuh) }\end{array}$ \\
\hline 2 & $\begin{array}{l}\mathrm{R} \text { square } \\
\text { (R2) adjusted } \\
\mathrm{v} \text { a riabe } 1 \\
\text { endogen }\end{array}$ & $\begin{array}{l}\text { Baik (0.670), } \\
\text { m o d e r a t } \\
(0.330), \text { dan } \\
\text { lemah }(0.190)\end{array}$ & $\begin{array}{l}0.399 \\
\text { (moderat) }\end{array}$ \\
\hline
\end{tabular}

Hasil bootstrapping model akhir penelitian pengaruh kompetensi alumni MAWAPRES terhadap kesuksesan karier dapat dilihat pada Gambar 13.

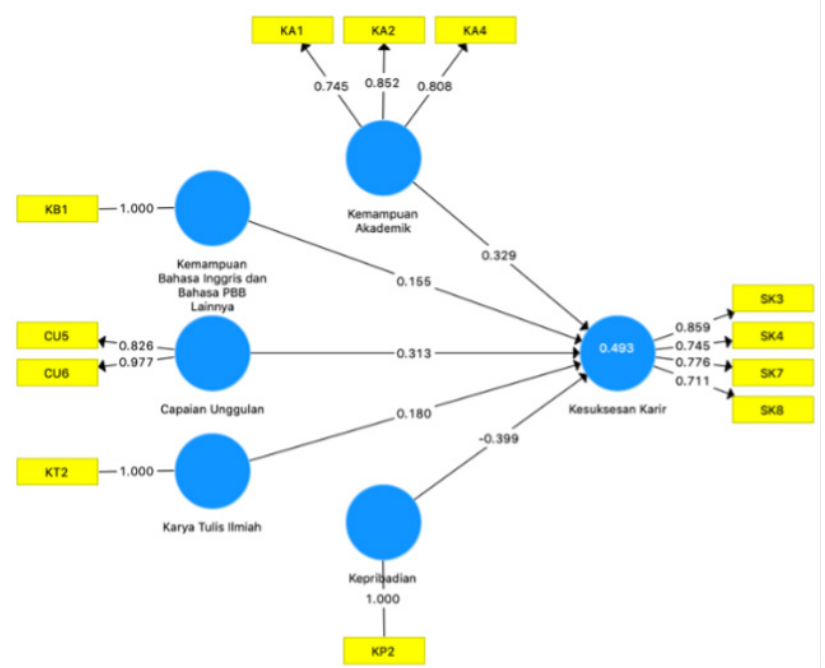

Gambar 13. Model Akhir Penelitian Pengaruh Kompetensi Alumni MAWAPRES terhadap Kesuksesan Karier

Nilai $t$-statistics setiap indikator pada vairabel Kemampuan Akademik (X1), kemampuan Bahasa Inggris dan Bahasa PBB lainnya (X2), capaian unggulan (X3), kemampuan membuat Karya Tulis Ilmiah (X4), Kepribadian (X5) dan Kesuksesan Karier (Y) tidak semuanya memiliki nilai lebih dari t-tabel, yaitu sebesar 1.960 dengan tingkat signifikansi 5\%. Artinya, indikator pada Gambar 13 tidak semuanya memiliki validitas yang signifikan. Langkah bootstrapping ini juga menghasilkan nilai original sample $(\mathrm{O})$, sample mean (M), kesalahan baku (standard errors), nilai $\neg$ t-statistic, dan $\mathrm{p}$-values pada nilai estimasi koefisien jalur (path coefficients). Teknik tersebut berguna untuk melihat pengaruh dan tingkat signifikansi variabel eksogen terhadap variabel endogen dan menguji hipotesis setiap jalur hubungan disajikan pada Tabel 16.

Tabel 8.

Hasil Path Coefficient

\begin{tabular}{|c|c|c|c|c|c|c|}
\hline & $\begin{array}{c}\text { Orig- } \\
\text { inal } \\
\text { Sam- } \\
\text { ple } \\
\text { (O) }\end{array}$ & $\begin{array}{l}\text { Sam- } \\
\text { ple } \\
M e- \\
a n \\
\text { (M) }\end{array}$ & $\begin{array}{c}\text { Stan- } \\
\text { dard } \\
\text { Devi- } \\
\text { ation } \\
\text { (ST- } \\
\text { DEV) }\end{array}$ & $\begin{array}{l}\text { T Sta- } \\
\text { tistic } \\
(\mid \mathrm{O} / \\
\text { ST- } \\
\text { DEV|) }\end{array}$ & $\begin{array}{c}\text { P- } \\
\text { Val- } \\
\text { ues }\end{array}$ & $\begin{array}{c}\text { Eval- } \\
\text { uasi } \\
\text { Mo- } \\
\text { del }\end{array}$ \\
\hline $\begin{array}{l}\text { Kemampuan } \\
\text { A kad emik } \\
(\mathrm{X} 1) \rightarrow \text { Ke- } \\
\text { s u k s e s a n } \\
\text { Karier }(\mathrm{Y})\end{array}$ & 0,329 & 0,369 & 0,186 & 1,773 & 0,077 & $\begin{array}{l}\text { Tidak } \\
\text { Sig- } \\
\text { nifi- } \\
\text { kan }\end{array}$ \\
\hline $\begin{array}{l}\text { Kemampuan } \\
\text { Bahasa Ing- } \\
\text { gris dan PBB } \\
\text { Lainnya (X2) } \\
\rightarrow \text { Kesuk- } \\
\text { sesan Karier } \\
\text { (Y) }\end{array}$ & 0,155 & 0,167 & 0,144 & 1,079 & 0.281 & $\begin{array}{l}\text { Tidak } \\
\text { Sig- } \\
\text { nifi- } \\
\text { kan }\end{array}$ \\
\hline $\begin{array}{l}\text { Capaian Un- } \\
\text { ggulan (X3) } \\
\rightarrow \text { Kesuk- } \\
\text { sesan Karier } \\
\quad \text { (Y) }\end{array}$ & 0,313 & 0,331 & 0,147 & 2,128 & 0,034 & $\begin{array}{l}\text { Sig- } \\
\text { nifi- } \\
\text { kan }\end{array}$ \\
\hline $\begin{array}{c}\text { Kemampuan } \\
\text { menulis KTI } \\
(\mathrm{X} 4) \rightarrow \text { Ke- } \\
\text { s u k s e s a n } \\
\text { Karier (Y) }\end{array}$ & 0,180 & 0,181 & 0,136 & 1,322 & 0,187 & $\begin{array}{l}\text { Tidak } \\
\text { Sig- } \\
\text { nifi- } \\
\text { kan }\end{array}$ \\
\hline $\begin{array}{l}\text { Kepribadi- } \\
\text { an }(X 5) \rightarrow \\
\text { Kesuksesan } \\
\text { Karier (Y) }\end{array}$ & $-0,399$ & $-0,397$ & 0,128 & 3,128 & 0,002 & $\begin{array}{l}\text { Sig- } \\
\text { nifi- } \\
\text { kan }\end{array}$ \\
\hline
\end{tabular}

Dari hasil path coefficient, diketahui bahwa terdapat perbedaan hubungan dari setiap variabel. Pertama, kemampuan akademik berpengaruh tidak signifikan terhadap kesuksesan karier dengan nilai t-statisitk sebesar 1,773. Kemudian kemampuan Bahasa Inggris dan PBB lainnya memiliki nilai t-statistik sebesar 1,079 sehingga berpengaruh tidak 
signifikan terhadap kesuksesan karier. Untuk capaian unggulan, diperoleh nilai t-statistik sebesar 2,128 atau dapat dikatakan berpengaruh signifikan terhadap kesuksesan karier. Sedangkan kemampuan menulis KTI memiliki nilai t-statistik sebesar 1,322 atau berpengaruh tidak signifikan terhadap kesuksesan karier. Terakhir, dari kepribadian diperolah nilai t-statistik 3,128 yang artinya berpengaruh signifikan terhadap kesuksesan karier.

\section{Implikasi Manajerial}

Profil alumni Mahasiswa Berprestasi IPB dapat dijadikan referensi untuk menghasilkan lulusan yang berkualitas. Dari segi akademik, mayoritas lulus dengan IPK di atas 3,50 atau berpredikat Dengan Pujian. Semasa kuliah, mayoritas alumni MAWAPRES IPB sudah memiliki kemampuan Bahasa inggris setara skor TOEFL 500, kemampuan menulis ilmiah dari karya tulis yang dihasilkan, prestasi dari berbagai kegiatan kompetitif dan kepemimpinan, serta kepribadian yang baik. Walaupun memiliki prestasi non-akademik, 65\% alumni tetap menyelesaikan studi tepat waktu. Masa tunggu pekerjaan para alumni juga sangat cepat, sebanyak $79 \%$ berada pada rentang 0 sampai 4 bulan setelah dinyatakan lulus dan mayoritas bekerja di perusahaan swasta.

Profil tersebut didukung dengan hasil analisa SEM yang menunjukkan bahwa kompetensi seperti kemampuan akademik, kemampuan Bahasa asing, capaian unggulan, kemampuan menulis ilmiah, serta kepribadian berpengaruh terhadap kesuksesan karier. Dari lima kompetensi tersebut, capaian unggulan dan kepribadian memiliki pengaruh yang signifikan.

Berdasarkan hasil perhitungan dan pembahasan analisis deskriptif dan SEM-PLS untuk program Diploma maupun Sarjana, IPB University perlu melakukan perbaikan kualitas pendidikannya agar kompetensi yang diperoleh semasa kuliah dapat mendukung kesuksesan karier pascakampus.

Dari input yang diperoleh tersebut, penulis mengusulkan agar IPB segera menerapkan kebijakan Kampus Merdeka untuk memberikan hak kepada mahasiswa untuk belajar di luar perguruan tinggi melalui berbagai kegiatan dan dari program studi lain. Kebijakan ini diluncurkan oleh Direktorat Jenderal Pendidikan Tinggi Kemdikbud RI (2020) dengan tujuan utama mendorong mahasiswa program Sarjana (S1) dan Sarjana Terapan (D4) untuk menguasai berbagai kompetensi yang akan berguna dalam dunia kerja. Kondisi pendidikan di perguruan tinggi saat ini membatasi fleksibilitas mahasiswa untuk mengikuti kegiatan di luar kelas yang seringkali berakibat pada penundaan kelulusan. Menurut Ditjen Dikti (2020), penerapan kebijakan Kampus Merdeka memungkinkan mahasiswa untuk mengambil satu semester di program studi yang berbeda dan beberapa semester di luar perguruan tinggi melalui berbagai kegiatan pilihan seperti magang, pertukaran pelajar, proyek di desa, wirausaha, riset, studi independen, serta kegiatan mengajar di daerah. Dengan begitu, diharapkan mahasiswa bisa mengasah berbagai kompetensi yang kelak bisa menunjang pencapaian kesuksesan karier pascakampus.

Menurut informasi dari Direktorat Program Internasional, sebelum kondisi pandemi rata-rata mahasiswa multistrata IPB yang mengikuti program pertukaran pelajar ke luar negeri sebanyak 1000 orang atau hanya 3\% dari total mahasiswa IPB tahun 2019 (DSITD IPB 2020). Sedangkan jumlah mahasiswa Sarjana yang mengikuti program magang bersertifikat pada tahun 2019 sebanyak 188 orang atau hanya 1\% dari total mahasiswa program Sarjana IPB (DitmawaPK IPB 2019b). Tentunya, diperlukan kerja sama berbagai pihak untuk menerapkan kebijakan Kampus Merdeka di IPB. Peneliti mengusulkan kerja sama quadruplehelix dengan pihak akademisi (academia), para pelaku bisnis (business), pemerintah (government), dan masyarakat maupun organisasi nirlaba (community).

Sumber pendanaan pelaksanaan program Merdeka Belajar bisa berasal dari Perguruan Tinggi, mitra, sumber lain yang tidak mengikat, serta mahasiswa bersangkutan (Ditjen Dikti 2020). Namun, mengaca kondisi saat ini beban finansial masih diserahkan kepada mahasiswa. Seperti program KKN-T dengan dana yang sedikit untuk satu kelompok, serta biaya yang perlu dikeluarkan untuk keperluan magang maupun pertukaran pelajar.

Peneliti percaya bahwa penerapan program Kampus Merdeka dari Kemendikbud dapat menjadi solusi atas input dalam penelitian ini. Tentunya, diperlukan kolaborasi semua pihak baik dari dalam unit maupun dari luar perguruan tinggi untuk menerapkan program-program agar bisa menghasilkan dampak yang optimal. Dengan memberikan hak bagi mahasiswa untuk mengasah kompetensi dan karakter yang diperlukan, harapannya dapat menghasilkan lebih banyak lulusan yang mampu meraih kesuksesan karier di tengah tantangan persaingan global.

\section{PENUTUP}

\section{Kesimpulan}

Dari penelitian ini, diperoleh tiga simpulan. Pertama, alumni MAWAPRES IPB program Diploma 
dan Sarjana dalam penelitian ini didominasi oleh laki-laki yang sebagian besar berdomisili di Jabotabek. Rata-rata alumni memiliki IPK yang sangat baik dan lulus tepat waktu yaitu 36 bulan untuk program Diploma dan 48 bulan untuk program Sarjana. Sedangkan yang melebihi masa tersebut mayoritas berkaitan dengan aktivitas kemahasiswaan. Setelah lulus, profesi alumni didominasi oleh karyawan swasta dengan masa tunggu rata-rata paling lama empat bulan.

Kedua, kompetensi alumni berdasarkan kriteria PILMAPRES sudah baik ditinjau dari kemampuan akademik dengan mayoritas memiliki IPK pada rentang nilai 3,51 sampai 4,00, kemampuan Bahasa Inggris yang sudah setara skor TOEFL PBT 500 / TOEFL iBT 60 / IELTS 6, memiliki capaian unggulan dari juara pada kegiatan kompetisi maupun memimpin dalam organisasi, karya tulis ilmiah yang dihasilkan, serta kepribadian yang didominasi oleh kecenderungan terhadap tipe Koleris. Dari segi karier pascakampus, mayoritas alumni sudah mencapai target karier rata-rata pada usia saat ini.

Ketiga, variabel capaian unggulan dan kepribadian berpengaruh signifikan terhadap kesuksesan karier, sedangkan kemampuan akademik, kemampuan Bahasa asing dan kemampuan penulisan ilmiah tidak berpengaruh signifikan.

\section{Saran}

Saran dari hasil penelitian ini diuraikan untuk beberapa pihak berikut (1) Direktorat Kemahasiswaan dan Pengembangan Karier selaku penyelenggara PILMAPRES tingkat IPB sebaiknya memperbaiki sistem arsip penilaian PILMAPRES ke dalam format digital, sehingga peneliti selanjutnya dapat menggunakan data yang lebih akurat sesuai dengan aspek penilaian yang berlaku; (2) Direktorat Kerjasama dan Hubungan Alumni (DKHA) IPB diharapkan bisa menjaga hubungan yang baik dengan alumni MAWAPRES IPB untuk memperbesar peluang kerjasama dalam meningkatkan kualitas lulusan IPB seperti pelaksanaan kelas persiapan karier, dan membuka akses kesempatan magang di perusahaan tempat alumni MAWAPRES bekerja; (3) Kementerian Pendidikan dan Kebudayaan (Kemdikbud), agar memperluas kesempatan bagi mahasiswa untuk mengikuti kegiatan kokurikuler dan ekstrakurikuler dengan memberikan beasiswa untuk pertukaran pelajar, penelitian independen, serta kegiatan wirausaha; (5) peneliti selanjutnya disarankan agar melakukan studi komparatif antara alumni yang pernah menjadi MAWAPRES dengan alumni non-Mawapres, atau dengan alumni Mawapres dari perguruan tinggi negeri lainnya yang sering menempati posisi teratas dalam Pilmapres tingkat nasional.

\section{DAFTAR PUSTAKA}

Abele, A. E, \& Spurk, D. (2009). "How Do Objective and Subjective Career Success Interrelate over Time?". Journal of Occupational and Organizational Psychology. 82(1), 803-24. DOI:10.1348/096317909X470924

BPS (Badan Pusat Statistik). (2019a). Indikator Pendidikan. Diakses dari https://www.bps. go.id/statictable/2010/03/19/1525/indikatorpendidikan-1994-2019.html pada tanggal 11 Juni 2020.

- - - (2019b). Keadaan Angkatan Kerja Di Indonesia Februari 2019. Jakarta (ID).

Ditjen Dikti (Direktorat Jenderal Pendidikan Tinggi). 2011. "Peraturan Direktur Jenderal Pendidikan Tinggi Kementerian Pendidikan Nasional Republik Indonesia Nomor 49/DIKTI/ Kep/2011 Tentang Pedoman Akreditasi."

Ditjen Dikti (Direktorat Jenderal Pendidikan Tinggi Kemdikbud RI). (2020). Buku Panduan Merdeka Belajar - Kampus Merdeka. Edisi pert. Jakarta (ID): Direktorat Jenderal Pendidikan Tinggi Kemdikbud RI.

DitmawaPK IPB (Direktorat Kemahasiswaan dan Pengembangan Karir IPB). (2019a). Laporan Akhir Tahun Fasilitasi Dan Monitoring Program Magang Mahasiswa 2019. Bogor (ID).

- - - . (2019b). Panduan Pemilihan Mahasiswa Berprestasi Tingkat IPB Tahun 2020. Bogor (ID): DitmawaPK IPB.

DKHA IPB (Direktorat Kerjasama dan Hubungan Alumni IPB). (2020). Kuesioner Tracer Study Lulusan Diploma Dan Sarjana. Diakses dari https://tracerstudy.ipb.ac.id/Web/ DiplomaSarjana/ pada tanggal 11 September 2020.

DSITD IPB (Direktorat Sistem Informasi dan Transformasi Digital). (2020). Jumlah Mahasiswa IPB University 2011-2019. Diakses dari . https://infografis.ipb.ac.id/index.php/ jumlah-mahasiswa-ipb-university-2011-

Dynarski, S., et al. 2017. Descriptive Analysis in Education: A Guide for Researchers. Washington DC: U.S. Department of Education, Institute 
of Education Sciences, National Center for Education Evaluation and Regional Assistance. 2019/pada tanggal 11 September 2020.

Garson, G. D. (2016). Partial Least Squares: Regression $\mathcal{E}$ Structural Equation Models. Asheboro (NC): Statistical Publishing Associates.

Greenhaus, J.H., Parasuraman. S., \& Wormley, W.M. (1990). "Effects Of Race On Organizational Experiences, Job Perform." Academy of Management Journal. 33(1), 64-86. DOI: $10.2307 / 256352$

Greenhaus, J.H., Callanan, G.A. \& Godshalk, V.M. (2010). Career Management 4th Edition. california (US): SAGE Publications, Inc.

Gregorová, A.B., Heinzová, Z., Chovancová, K. (2016). The Impact of Service-Learning on Students' Key Competences. The International Journal of Research on Service-Learning and Community Engagement. 4(1), 367-376. Retrieved from https://journals.sfu.ca/iarslce/index.php/ journal/article/view/246

Ikhsan, W.N. (2019). “Development of Management Trainee Program (Case Study on PT. X Consumer Goods Company in Jakarta)." PROCURATIO. 7(1), 1-9. Retrieved from http:/ / www.ejournal.pelitaindonesia.ac.id/ ojs32/index.php/PROCURATIO/article/ view/305

IPB University. (2020). IPB and Mandiri Bank Collaborates to Create Entrepeneurs By Design. Diakses dari https://ipb.ac.id/news/ index / 2020/07/ipb-and-mandiri-bankcollaborates-to-create-entrepeneurs-by-design/ a895d1f1562825bb14bb401b43cd0038 pada tanggal 1 September 2020.

Kaiser, R.B.S., et.al. (2011). “Differences in Managerial Jobs at the Bottom, Middle, and Top: A Review of Empirical Research." PsychologistManager Journal. 14(2), 76-91. DOI: 10.1080/10887156.2011.570137

Kemristekdikti. (Kementerian Riset Teknologi dan Pendidikan Tinggi). (2017). Pedoman Pemilihan Mahasiswa Berprestasi. Jakarta (ID): Kemristekdikti. http://pilmapres.ristekdikti. go.id/file/pendukung/2017/PEDOMAN_ PILMAPRES_SARJANA_2017.pdf.

- - - . (2019). Panduan Sistem Informasi Manajemen Pemeringkatan Kemahasiswaan (SIMKATMAWA). Jakarta (ID): Kemristekdikti.

Lakshmi, P.A.V \& Sumaryono. (2019). Kesuksesan Karier Ditinjau dari Persepsi Pengembangan Karier dan Komitmen Karier pada Pekerja
Millennial. Gadjah Mada Journal of Psychology. 14(1), 57-75. DOI: 10.22146/gamajop.45782

Lester, S.W.; et al. (2010). "The Impact of Passing the Professional in Human Resources Exam on Early Career Success for Undergraduates Entering the Human Resource Field." International Journal of Selection and Assessment. 18(3), 282-90. DOI: 10.1111/j.1468-2389.2010.00511.x

Littauer, F. 1992. Personality Plus. New York(USA): F.H. Revell Co.

LPDP (Lembaga Pengelola Dana Pendidikan). (2020). Beasiswa Reguler. Diakses dari https://www. lpdp.kemenkeu.go.id/in/page/beasiswareguler pada tanggal 3 Januari 2020.

McDonald, K.S. \& Hite, L.M. (2008). “The Next Generation of Career Success: Implications for HRD." Advances in Developing Human Resources. 10(1), 86-103. DOI: 10.1177/1523422307310116

Miracle, V.A. (2007). "Thinking about Certification." Dimensions of Critical Care Nursing. 26(2), 72-75. DOI: 10.1097/00003465-200703000-00008

Neuman, W.L. (2014). Social Research Methods: Qualitative and Quantitative Approaches. Seventh Ed. Edinburgh (UK): Pearson Education Limited.

Puspresnas (Pusat Prestasi Nasional). (2020). Petunjuk Pelaksanaan Pemilihan Mahasiswa Berprestasi Tahun 2020. Jakarta: Pusat Prestasi Nasional, Kemdikbud RI.

Oliveira, M, L Melo-Silva, M Taveira, and R Grace. 2016. "Measuring University-to-Work Success: Development of a New Scale." Career Development International. 21(1), 85-104. DOI: 10.1108/CDI-04-2015-0051

Rogeleonick, A \& Anugrahmawaty, D. (2020). Berbadan Hukum, PTN Lebih Mandiri dan Dinamis. Diakses dari https:/ / www.kemdikbud.go.id/main/ blog/2020/02/berbadan-hukum-ptn-lebihmandiri-dan-dinamis pada tanggal 15 April 2020.

Schomburg, H. (2016). Carrying Out Tracer Studies: Guide to Anticipating and Matching Skills and Jobs. Luxembourg: Publication Office of the European Union.

Shockley, K.M.; et al. (2015). “Development of a New Scale to Measure Subjective Career Success: A Mixed-Methods Study." Journal of Organizational Behavior. 37(1), 128-53. DOI: 10.1002/job.2046

Spencer, L.M, \& Spencer, S.M. (1993). Competence at Work: Models for Superior Performance. New York(USA): Wiley.

Spurk, D., Abele, A.E. \& Volmer, J. (2011). “The Career 
Satisfaction Scale: Longitudinal Measurement Invariance and Latent Growth Analysis." Journal of Occupational and Organizational. Psychology 84(2), 315-26. DOI: 10.1111/j.20448325.2011.02028.x

Sunggingwati, D. (2018). "Reading and Writing Skills of Scientific Articles for Undergraduate Students: Benefits and Challenges." Advances in Social Science, Education and Humanities Research. 164 (1), 167-171. DOI: 10.2991/icli17.2018.32

UNDP (United Nations Development Programme). (2019). United Nations Development Programme Human Development Report 2019: Beyond Income, beyond Averages, beyond Today. New York(USA): United Nations Development Programme.

Weeden, K.A. (2002). “Why Do Some Occupations Pay More than Others? Social Closure and Earnings Inequality in the United States." American Journal of Sociology. 108(1), 55-101. DOI: $10.1086 / 344121$

Yusuf, K \& Mabagits, S. (2020). “Does Activeness in Organization Improve English Speaking Skill?: University Students' Perspective." Leksika: Jurnal Bahasa, Sastra dan Pengajarannya. 14(2), 73-77. Retrieved from http://jurnalnasional. ump.ac.id/index.php/LEKSIKA/article/ view $/ 7383 / 3311$ 